\title{
STUDI KOMPUTASI ALIRAN PEMANAS PADA INKUBATOR TELUR BERKAPASITAS 400 TELUR DENGAN MENGGUNAKAN SUMBER PANAS BUMI BERENTALPI RENDAH
}

\author{
Jooned Hendrarsakti ${ }^{1}$ Muhammad Faisal Fachri ${ }^{2}$, M. Arifudin Lukmana ${ }^{3}$ \\ Fakultas Teknik, Universitas Pembangunan Nasional “Veteran” Jakarta ${ }^{1} 3$ \\ Fakultas Teknik Mesin dan Dirgantara, Institut Teknologi Bandung ${ }^{12}$ \\ Jalan Ganesha 10, Bandung $40132^{1,3}$ \\ email $^{1}$ : jooned@ftmd.itb.ac.id
}

\begin{abstract}
This study aims to analyze the possibility of using geothermal energy as an alternative energy source for the egg incubator hatchery with capacity of 400 eggs. Geothermal resource used in the process of retrofitting has a temperature of $70^{\circ} \mathrm{C}$ with a maximum flow of 2 liters/s in accordance with the data of geothermal resources at Tangeung Cibugur, Cianjur regency.

Based on the results of the feasibility studies that have been done, the source of geothermal energy can be used for heating egg incubator in order to reach adequate incubation conditions (temperature 36 to $38.5^{\circ} \mathrm{C}$ and a relative humidity of 50-60\%). In the process of retrofitting, the design of the incubator used is forced draft incubator. Its components are heat exchanger, fans, and a water tray. The type of heat exchanger that used is cross flow, one fluid mixed, one fluid unmixed. It uses a staggered arrangement of copper pipe as a heat exchange surface.

Incubator with geothermal energy is well used by using 5 fans with volume flow rate $0,0094-0,0141 \mathrm{~m}^{3} / \mathrm{s}$ on the condition of the inlet air temperature is $23-27^{\circ} \mathrm{C}$ and $a$ minimum pipe temperature is $65^{\circ} \mathrm{C}$.
\end{abstract}

Keywords: incubator, geothermal, egg, alternative energy.

\section{PENDAHULUAN}

Inkubator telur adalah alat yang digunakan untuk menetaskan telur dengan cara menyediakan kondisi yang sesuai untuk perkembangan telur. Kondisi dalam ruangan inkubator harus memiliki temperatur $36-38,5^{\circ} \mathrm{C}$ dan kelembaban relatif 50 $60 \%$ agar dapat memberikan lingkungan yang baik untuk perkembangan telur [1]. Bagi peternak skala kecil di Indonesia, inkubator yang biasa digunakan adalah jenis inkubator konvensional. Inkubator jenis ini hanya memiliki fasilitas berupa pemanas yang biasa berupa lampu pijar untuk menghangatkan ruangan inkubator, wadah telur untuk menempatkan telur yang akan ditetaskan, dan wadah berisi air untuk menjaga kelembaban ruangan inkubator. Sedangkan untuk inkubator modern yang biasa digunakan oleh peternakan skala industri memiliki fasilitas yang lebih canggih seperti pemutar telur otomatis, sensor dan pengatur temperatur ruangan, dan pengatur kelembaban ruangan

Untuk menunjang program pemberdayaan energy baru dan terbarukan, sumber pemanas dari inkubator dapat menggunakan sumber panas bumi secara langsung dari panas bumi. Dalam studi ini, akan dilakukan studi komputasi aliran dalam inkubator dengan system pemanas yang menggunakan sumber panas bumi cair bersuhu rendah $\left(<70^{\circ} \mathrm{C}\right)$

Oleh karena itu, retrofitting energi panas bumi sebagai pemanas inkubator telur berkapasitas 400 telur menggunakan studi analitik dan komputasi ini dilakukan. Penelitian ini diharapkan dapat mendorong pemakaian energi baru dan terbarukan dan membuat peternakan di sekitar daerah yang dekat dengan sumber panas bumi lebih kompetitif dan dapat meningkatkan kesejahteraan masyarakat di daerah sekitar sumber panas bumi.

\section{Tujuan Penelitian}

Tujuan dari penelitian pada penelitian ini adalah sebagai berikut melakukan (1) studi komputasi persebaran temperatur dan kecepatan yang terjadi dalam ruangan incubator, dan (2) studi kelayakan potensi energi panas bumi sebagai pemanas untuk inkubator telur 
konvensional dengan kapasitas 400 telur pada daerah pedesaan.

\section{DASAR TEORI}

\section{Proses Pengeraman Telur}

Perkembangan embrio unggas tidak terjadi di dalam tubuh induknya, tetapi terjadi di dalam telur. Agar telur dapat menetas dan melahirkan anak unggas, telur harus mengalami proses pengeraman atau proses inkubasi telebih dahulu. Proses pengeraman atau inkubasi adalah proses penyimpanan telur pada kondisi yang sesuai agar embrio dapat berkembang dengan baik. Proses inkubasi dapat dilakukan dengan dua cara, yaitu dengan induk (natural incubation) dan dengan mesin penetas telur (artificial incubation). Proses pengeraman telur sampai akhirnya telur menetas membutuhkan waktu yang bervariasi tergantung pada jenis telur. Telur ayam (Gallus gallus domesticus) membutuhkan waktu 21 hari untuk menetas [1].

Terdapat empat kondisi pengeraman yang harus dijaga agar perkembangan embrio terjadi dengan baik dan telur dapat menetas [1] yaitu: temperatur pengeraman. $36-38,5^{\circ} \mathrm{C}$, penempatan dan pemutaran telur, kelembaban udara di kelembaban relatif 50-60\%, sirkulasi udara untuk embrio yang membutuhkan oksigen untuk bernafas.

Inkubator telur atau mesin penetas telur adalah sebuah alat yang digunakan untuk untuk menetaskan telur dengan cara menciptakan kondisi yang sesuai untuk perkembangan embrio di dalam telur. Untuk dapat menetaskan telur, inkubator harus menyediakan kondisi temperatur, kelembaban udara, mekanisme pemutaran telur, dan juga sirkulasi udara yang baik bagi telur.

Jenis Inkubator Telur dapat diklasifikasikan menjadi tiga jenis, yaitu [2]: Still air incubator dan Contact incubator. Dari kedua tipe tersebut, contact incubator lebih sering digunakan. Contact incubator mengadopsi metode penetasan yang dilakukan oleh induk terhadap telur, yaitu adanya permukaan kontak antara inkubator dan telur. Untuk menjadi pemanas ruangan inkubator telur, maka sumber panas harus memiliki temperatur yang lebih tinggi daripada temperatur pengeraman telur, yaitu $36-38,5^{\circ} \mathrm{C}$. Sebagai contoh, manifestasi panas bumi pada daerah Tangeung - Cibugur memiliki temperatur fluida $69-70,5^{\circ} \mathrm{C}$, pH 6,8, dan debit 2,0 liter/s [3]

Data temperatur dan debit dari manifestasi geothermal berguna untuk mengetahui besarnya entalpi yang dimiliki oleh fluida geothermal, dan kemudian dapat digunakan untuk pertimbangan kapasitas inkubator. Sedangkan nilai $\mathrm{pH}$ dapat digunakan untuk pertimbangan penentuan material penukar panas.

Berdasarkan studi yang telah dilakukan mengenai inkubator telur dan juga potensi energi panas bumi di beberapa daerah di Indonesia, inkubator telur dengan energi panas bumi adalah sebagai berikut: jenis forced draft incubator, kapasitas 400 butir telur, kondisi temperatur 36 - 38,5 $5^{\circ} \mathrm{C}$ dan kelembaban udara 50 - 60\% pada tempat peletakkan telur.

\section{Sistem Pemanfaatan Energi Panas Bumi untuk Inkubator Telur}

Pada pemanfaatan energi panas bumi untuk inkubator telur, energi panas bumi digunakan sebagai pemanas udara dalam inkubator telur agar temperatur udara dalam inkubator berada pada temperatur pengeraman telur. Dalam pemanfaatannya, diperlukan sebuah sistem penukar panas yang memindahkan panas dari fluida panas bumi ke udara pada inkubator telur. Sistem penukar panas tersebut ditunjukkan pada Gambar 1.

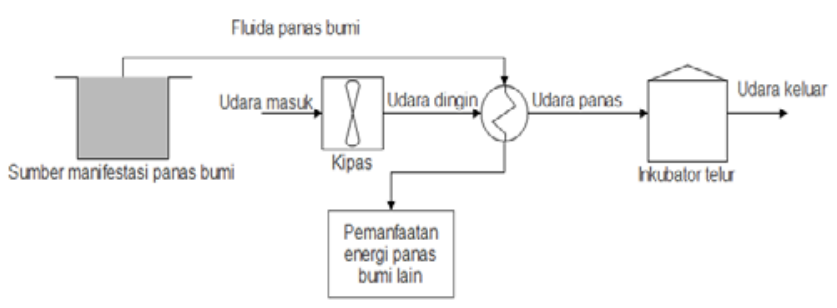

Gambar 1 Skema sistem penukar panas inkubator dengan energi panas bumi.

Pada Gambar 1 dapat dilihat fluida panas bumi dialirkan dari sumber manifestasi panas bumi menggunakan pipa menuju penukar panas. Sedangkan, udara disuplai menuju penukar panas dengan menggunakan kipas. Pada penukar panas, terjadi perpindahan panas dari fluida panas bumi ke udara yang disuplai oleh kipas. Udara yang telah mencapai temperatur pengeraman kemudian dialirkan ke dalam tempat peletakkan telur di ruangan inkubator.

\section{Konsep Desain Inkubator Telur}

Inkubator telur dengan energi panas bumi sebagai pemanas dirancang dengan lima komponen penyusun, yaitu ruangan inkubator, wadah telur, wadah air, kipas, dan penukar panas. Pada desain ini, kipas dan penukar panas berada dalam ruangan inkubator. Pada perancangan inkubator ini, jenis inkubator yang dipilih adalah forced draft incubator, karena menggunakan kipas yang berfungsi untuk mengalirkan udara 
menuju penukar panas dan membuat temperatur udara di dalam ruangan inkubator lebih merata.

Pada inkubator ini, penukar panas yang digunakan adalah jenis cross flow heat exchanger one fluid mixed one fluid unmixed. Permukaan penukar panas yang digunakan adalah pipa tembaga, seperti yang ditunjukkan pada Gambar 2. Jenis penukar panas ini dipilih karena mempertimbangkan kemudahan dalam pembuatan dan kemudahan dalam modifikasi pada inkubator telur yang ada.

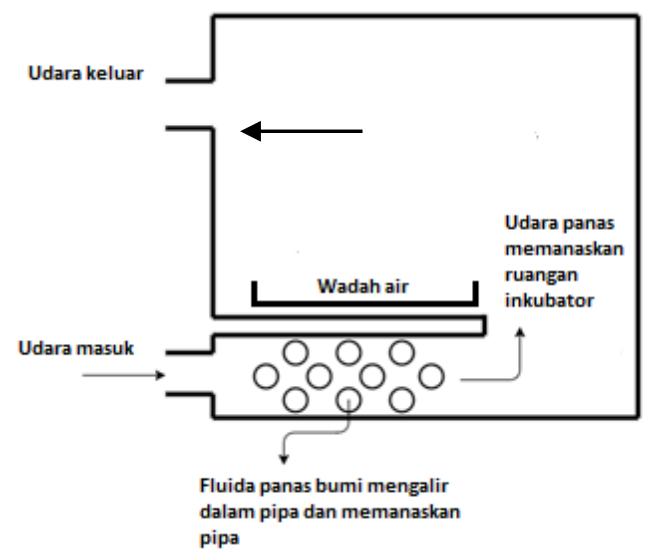

Gambar 2. Skema inkubator telur dengan energi panas bumi sebagai pemanas

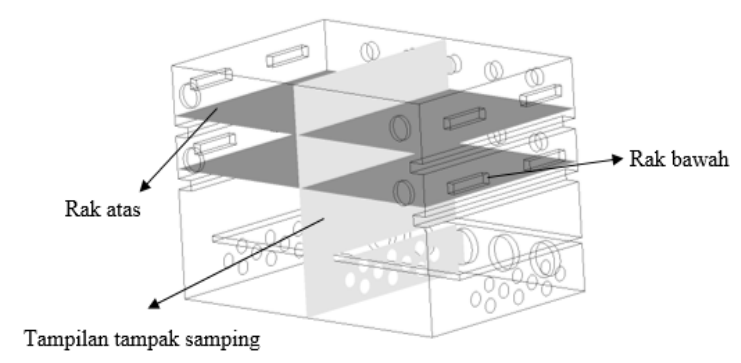

Gambar 3. Permukaan analisis hasil studi komputasi.

Pada Gambar 2 terlihat di bagian bawah inkubator terdapat susunan pipa penukar panas. Pipa penukar panas berisi fluida panas bumi yang mengalir di dalam pipa, yang kemudian memanaskan pipa. Sedangkan udara masuk kedalam inkubator telur dengan menggunakan kipas. Udara yang masuk inkubator kemudian melewati pipa penukar panas sehingga terjadi perpindahan panas dari pipa penukar panas ke udara. Udara panas yang telah melewati pipa penukar panas kemudian akan menuju ruangan tempat penyimpanan telur, lalu memanaskan ruangan tersebut. Di bagian atas inkubator dapat dilihat pada Gambar 3 menunjukan bidang yang akan dianalisis.
Tabel 1 Karakteristik dan kondisi pengeraman telur ayam [3].

\begin{tabular}{|l|l|}
\hline Karakteristik & Nilai \\
\hline Lama pengeraman & 21 hari \\
\hline Ukuran telur & $\begin{array}{l}\text { Panjang } 57,0 \mathrm{~mm} \\
\text { Diameter } 44,5 \mathrm{~mm}\end{array}$ \\
\hline $\begin{array}{l}\text { Temperatur ruangan } \\
\text { inkubator }\end{array}$ & $36-38,5^{\circ} \mathrm{C}$ \\
\hline $\begin{array}{l}\text { Kelembaban relatif } \\
\text { ruangan incubator }\end{array}$ & $50-60 \%$ \\
\hline Sudut pemutaran telur & $180^{\circ}$ \\
\hline
\end{tabular}

Untuk memperoleh kondisi pengeraman pada Tabel 1, maka dilakukan perancangan ruangan inkubator, penukar panas, dan wadah air. Perancangan ruangan inkubator didasarkan pada ukuran telur ayam. Kapasitas dari inkubator ini adalah 400 telur. Dalam perancangan penukar panas, data fluida panas bumi yang digunakan diambil dari data manifestasi panas bumi di Cibugur, Cianjur dengan karakteristik seperti yang ditunjukkan pada Tabel 2.

Tabel 2. Karakteristik manifestasi panas bumi di daerah Cianjur.

\begin{tabular}{|l|l|}
\hline Temperatur & $69,1-70,5^{\circ} \mathrm{C}$ \\
\hline $\mathrm{pH}$ & 6,8 \\
\hline Debit & 2,0 liter/s \\
\hline
\end{tabular}

Pada studi komputasi awal, simulasi dilakukan dengan keadaan sesuai dengan hasil analitik. Parameter pada simulasi awal ditunjukkan pada Tabel 3.

Tabel 3. Parameter pada studi komputasi awal

\begin{tabular}{|l|l|}
\hline Temperatur pipa & $70^{\circ} \mathrm{C}$ \\
\hline $\begin{array}{l}\text { Temperatur udara } \\
\text { masuk }\end{array}$ & $25^{\circ} \mathrm{C}$ \\
\hline Jumlah kipas & 5 buah \\
\hline Laju massa total & $0,075 \mathrm{~kg} / \mathrm{s}$ \\
\hline Susunan pipa & 7 baris \\
\hline
\end{tabular}

Tabel 4 Variasi susunan pipa.

\begin{tabular}{|l|l|l|}
\hline & $\begin{array}{l}\text { Temperatur } \\
\text { pipa }\end{array}$ & $70^{\circ} \mathrm{C}$ \\
\cline { 2 - 3 } & $\begin{array}{l}\text { Temperatur } \\
\text { udara masuk }\end{array}$ & $25^{\circ} \mathrm{C}$ \\
\cline { 2 - 3 } & Jumlah kipas & $5 \mathrm{buah}$ \\
\cline { 2 - 3 } & Laju massa & $0,075 \mathrm{~kg} / \mathrm{s}$ \\
\hline
\end{tabular}




\begin{tabular}{|c|c|c|}
\hline & total & \\
\hline \multirow{3}{*}{ 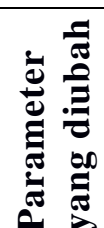 } & \multirow{3}{*}{$\begin{array}{l}\text { Pola susunan } \\
\text { pipa }\end{array}$} & 7 baris \\
\hline & & $\begin{array}{l}4 \text { baris, baris } \\
\text { terdepan } 3 \text { pipa }\end{array}$ \\
\hline & & $\begin{array}{l}4 \text { baris, baris } \\
\text { terdepan } 2 \text { pipa }\end{array}$ \\
\hline
\end{tabular}

Tabel 5 Variasi jumlah kipas.

\begin{tabular}{|c|c|c|}
\hline \multirow{4}{*}{ 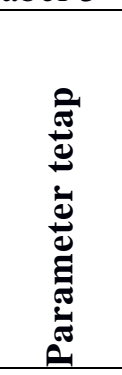 } & $\begin{array}{l}\text { Temperatur } \\
\text { pipa }\end{array}$ & $70^{\circ} \mathrm{C}$ \\
\hline & $\begin{array}{l}\text { Temperatur } \\
\text { udara masuk }\end{array}$ & $25^{\circ} \mathrm{C}$ \\
\hline & $\begin{array}{l}\text { Pola susunan } \\
\text { pipa }\end{array}$ & 7 baris \\
\hline & $\begin{array}{l}\text { Laju massa } \\
\text { kipas }\end{array}$ & $0,075 \mathrm{~kg} / \mathrm{s}$ \\
\hline 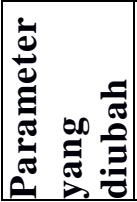 & Jumlah kipas & $2,3,4,5,6$ \\
\hline
\end{tabular}

Tabel 6. Variasi temperatur pipa.

\begin{tabular}{|c|c|c|}
\hline \multirow{4}{*}{ 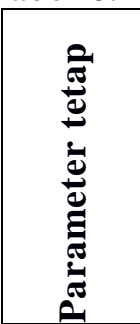 } & Jumlah kipas & 5 buah \\
\hline & $\begin{array}{l}\text { Temperatur } \\
\text { udara masuk }\end{array}$ & $25^{\circ} \mathrm{C}$ \\
\hline & $\begin{array}{l}\text { Pola susunan } \\
\text { pipa }\end{array}$ & 7 baris \\
\hline & $\begin{array}{l}\text { Laju massa } \\
\text { kipas }\end{array}$ & $0,075 \mathrm{~kg} / \mathrm{s}$ \\
\hline \multirow{2}{*}{ 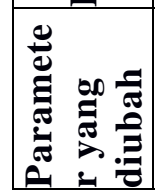 } & \multirow{2}{*}{$\begin{array}{l}\text { Temperatur } \\
\text { pipa }\end{array}$} & $\begin{array}{l}55^{\circ} 60^{\circ} 65^{\circ} \text { dan } \\
70^{\circ} \mathrm{C}\end{array}$ \\
\hline & & \\
\hline
\end{tabular}

Tabel 7. Variasi temperatur udara masuk.

\begin{tabular}{|c|c|c|}
\hline \multirow{4}{*}{ 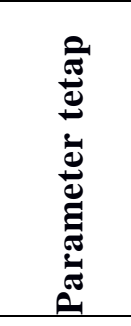 } & Jumlah kipas & 5 buah \\
\hline & $\begin{array}{l}\text { Temperatur } \\
\text { pipa }\end{array}$ & $70^{\circ} \mathrm{C}$ \\
\hline & $\begin{array}{l}\text { Pola susunan } \\
\text { pipa }\end{array}$ & 7 baris \\
\hline & $\begin{array}{l}\text { Laju massa } \\
\text { kipas }\end{array}$ & $0,075 \mathrm{~kg} / \mathrm{s}$ \\
\hline 窇 & $\begin{array}{l}\text { Temperatur } \\
\text { pipa }\end{array}$ & $\begin{array}{l}19^{\circ} \mathrm{C}, 21^{\circ} \mathrm{C}, \\
23^{\circ} \mathrm{C}, 25^{\circ} \mathrm{C}, \\
27^{\circ} \mathrm{C}, 29^{\circ} \mathrm{C}\end{array}$ \\
\hline
\end{tabular}

Kemudian akan dilakukan analisis mengenai pengaruh dari beberapa parameter terhadap persebaran temperatur dan kecepatan pada distribusi temperatur di rak atas dan rak bawah inkubator telur. Parameter-parameter tersebut adalah susunan pipa, jumlah kipas, temperatur pipa, dan temperatur udara masuk. Keempat parameter tersebut divariasikan untuk mengetahui pengaruhnya pada distribusi temperatur dan kecepatan pada inkubator telur. Variasi dari keempat parameter tersebut ditunjukkan oleh Tabel 4-7.

\section{Kondisi Batas Studi Komputasi}

Dalam studi, pemecahan menggunakan asumsi aliran incompressible dengan properti konstant untuk fluida Newtonian. Konservasi massa dan moementum didapatkan persamaan dinamik

$$
\begin{gathered}
\frac{\partial u_{i}}{\partial x_{j}}=0 \\
\frac{\partial u_{i}}{\partial t}+\frac{\partial u_{i} u_{j}}{\partial x_{j}}=-\frac{1}{\rho} \frac{\partial p}{\partial x_{i}}+\frac{1}{\rho} \frac{\partial \tau_{i j}}{\partial x_{j}}
\end{gathered}
$$

Dimana $\mathrm{u}_{\mathrm{I}}$ adalah komponen ke-i dari kecepatan fluida, $\rho$ (konstanta) adalah massa jenis fluida, dan $\tau_{\mathrm{ij}}$ adalah simetrik stress tensor. Untuk constant property dari fluid incompressible dan Newtonian, $\tau_{i j}$ $=2 \mu \mathrm{S}_{\mathrm{ij}}$, dimana $\mathrm{p}$ adalah tekanan statik, $\mu$ adalalah viskositas dinamik, dan $\mathrm{S}_{\mathrm{ij}}$ adalah tensor laju strain.

Studi komputasi mengunakan Finite Volume Method dilakukan untuk mengetahui distribusi temperatur dan kecepatan dalam ruangan inkubator. Distribusi temperatur perlu diketahui untuk memastikan temperatur udara dalam inkubator telah berada pada rentang temperatur pengeraman. Pada studi komputasi ini, kondisi batas yang digunakan ditunjukkan pada Tabel 8.

\section{Pengaruh Susunan Pipa terhadap Distribusi Temperatur Tempat Peletakkan Rak Telur.}

Pada simulasi ini, susunan pipa dibuat dengan 3 variasi. Simulasi variasi susunan pipa dilakukan untuk menganalisis pengaruh susunan pipa terhadap distribusi temperatur udara pada tempat peletakkan rak bawah dan rak atas inkubator telur. Selain itu, dalam simulasi ini juga dapat ditentukan susunan pipa yang dapat menghasilkan distribusi temperatur terbaik pada tempat peletakkan rak atas dan rak bawah utuk digunakan pada inkubator.

Tabel 8. Kondisi batas dan alasan penggunaannya pada studi komputasi.

\begin{tabular}{|l|l|}
\hline Kondisi Batas & Alasan Penggunaan \\
\hline $\begin{array}{l}\text { Inlet menggunakan } \\
\text { mode mass flow inlet } \\
\text { dengan laju massa } \\
0,075 \mathrm{~kg} / \mathrm{s} \text { dan } \\
\text { temperatur inlet } \\
\text { udara } 25^{\circ} \mathrm{C} .\end{array}$ & $\begin{array}{l}\text { Mode mass flow inlet } \\
\text { dipilih karena fluida yang } \\
\text { digunakan fluida gas. Nilai } \\
\text { mass flow rate dan } \\
\text { temperatur inlet } \\
\text { disesuaikan dengan hasil } \\
\text { perhitungan. }\end{array}$ \\
\hline $\begin{array}{l}\text { Outlet menggunakan } \\
\text { jenis pressure outlet } \\
\text { dengan pressure } \\
\text { gauge bernilai } 0 .\end{array}$ & $\begin{array}{l}\text { Mode pressure outlet baik } \\
\text { digunakan untuk velocity } \\
\text { inlet ataupun mass flow } \\
\text { inlet. Pressure gauge } \\
\text { bernilai 0 karena inkubator } \\
\text { telur terbuka ke atmosfer, } \\
\text { jadi tekanan antara dalam } \\
\text { ruangan dan luar ruangan } \\
\text { inkubator sama. }\end{array}$ \\
\hline
\end{tabular}




\begin{tabular}{|c|c|}
\hline $\begin{array}{l}\text { Pipa didefinisikan } \\
\text { menjadi wall. } \\
\text { Material yang } \\
\text { digunakan adalah } \\
\text { Copper dengan } \\
\text { temperatur bernilai } \\
70^{\circ} \mathrm{C} \text {. }\end{array}$ & $\begin{array}{l}\text { Ketebalan pipa } \\
\text { diasumsikan sangat tipis } \\
\text { sehingga temperatur pipa } \\
\text { dibuat sama dengan } \\
\text { temperatur fluida panas } \\
\text { bumi dalam perhitungan. }\end{array}$ \\
\hline $\begin{array}{l}\text { Wall solid yang } \\
\text { merupakan ruangan } \\
\text { inkubator } \\
\text { didefinisikan sebagai } \\
\text { wall dengan } \\
\text { temperatur } 36^{\circ} \mathrm{C} \text { dan } \\
\text { material wood. }\end{array}$ & $\begin{array}{l}\text { Temperatur dinding } \\
\text { ruangan inkubator telur } \\
\text { ditentukan berdasarkan } \\
\text { pada perhitungan. }\end{array}$ \\
\hline
\end{tabular}

Susunan pipa staggered 10 pipa dapat dibentuk menjadi 3 pola susunan pipa, yaitu pola susunan 1 (7 baris), pola susunan pipa 2 (4 baris dengan baris terdepan 2 pipa), dan pola susunan pipa 3 (4 baris dengan baris terdepan 3 pipa), seperti yang ditunjukkan pada Gambar 4. Pada simulasi ini, selain pola susunan pipa, parameter lain dibuat tetap, seperti yang telah dijelaskan pada Tabel 4, dimana laju massa udara total bernilai $0,075 \mathrm{~kg} / \mathrm{s}$, jumlah kipas 5 buah, temperatur udara masuk $25^{\circ} \mathrm{C}$, dan temperatur pipa $70^{\circ} \mathrm{C}$.
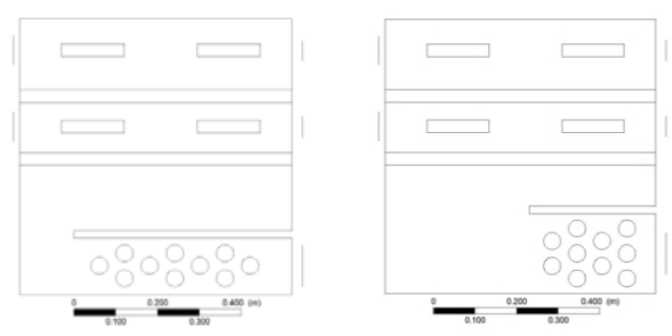

(a) Susunan pipa 1

(b)Susunan pipa 2

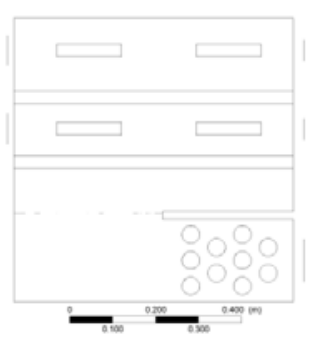

(c) Susunan pipa 3

Gambar 4. Variasi susunan pipa penukar panas

Berdasarkan hasil simulasi, susunan pipa yang berbeda menghasilkan distribusi temperatur yang berbeda pula pada rak atas dan rak bawah inkubator telur, seperti yang ditunjukkan pada Gambar 5. Gambar 5 juga menunjukkan bahwa inkubator dengan susunan pipa 1 menghasilkan distribusi temperatur udara yang lebih baik dibandingkan dengan inkubator dengan susunan pipa 2 ataupun 3. Hal ini disebabkan pada inkubator dengan susunan pipa 1 distribusi temperatur udara pada tempat peletakkan rak bawah dan rak atas seluruhnya berada pada rentang temperatur pengeraman, yaitu 36,0 $38,5^{\circ} \mathrm{C}$. Sedangkan, pada inkubator dengan susunan pipa 2 dan 3, terdapat daerah dimana temperatur udara pada rak bawah dan rak atas berada diluar temperatur pengeraman.

Pada inkubator dengan susunan pipa 1 , seperti yang telah dijelaskan pada pembahasan hasil studi komputasi awal, daerah terluas pada rak bawah dan rak atas memiliki temperatur udara $37,00-37,25^{\circ} \mathrm{C}$. Selain itu, pada sudut depan inkubator dengan susunan pipa 1 , terdapat daerah yang memiliki temperatur yang lebih tinggi dibanding daerah lainnya. Penyebab dari fenomena ini adalah terjadinya vortex di sudut depan inkubator pada tempat peletakkan rak bawah.

Pada inkubator dengan susunan pipa 2, hampir seluruh daerah pada tempat peletakkan rak bawah berada pada rentang temperatur pengeraman. Tetapi masih ada daerah yang temperatur nya dibawah $36^{\circ} \mathrm{C}$, seperti yang ditunjukkan pada Gambar 5(c). Sedangkan pada rak atas, seluruh daerah berada pada temperatur pengeraman. Daerah terluas pada rak bawah dan rak atas memiliki temperatur udara dengan rentang $36,0-36,5^{\circ} \mathrm{C}$.

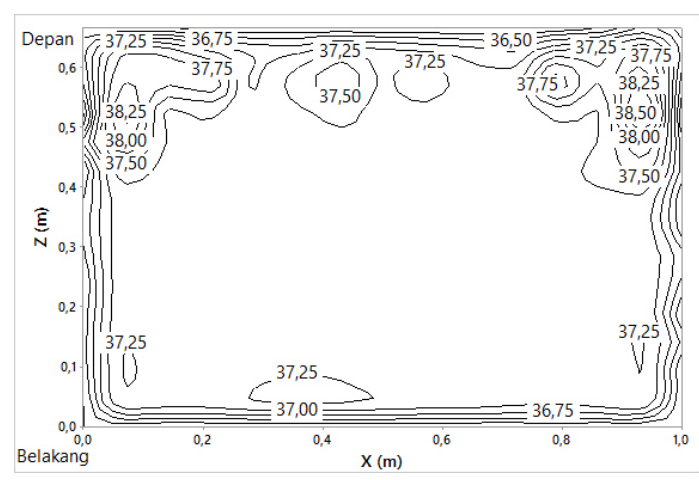

(a) Rak bawah (susunan pipa 1)

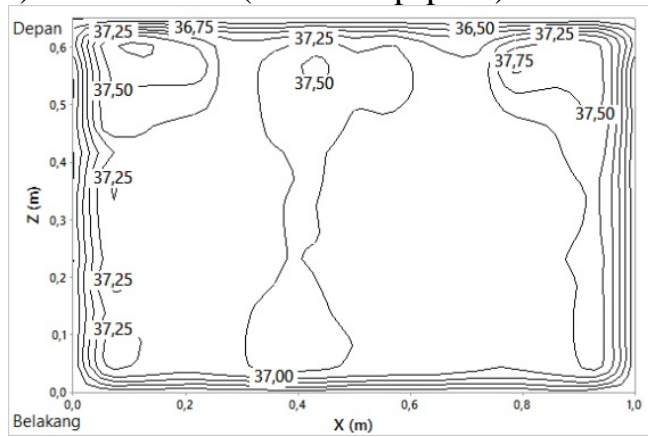

(b) Rak atas (susunan pipa 1) 


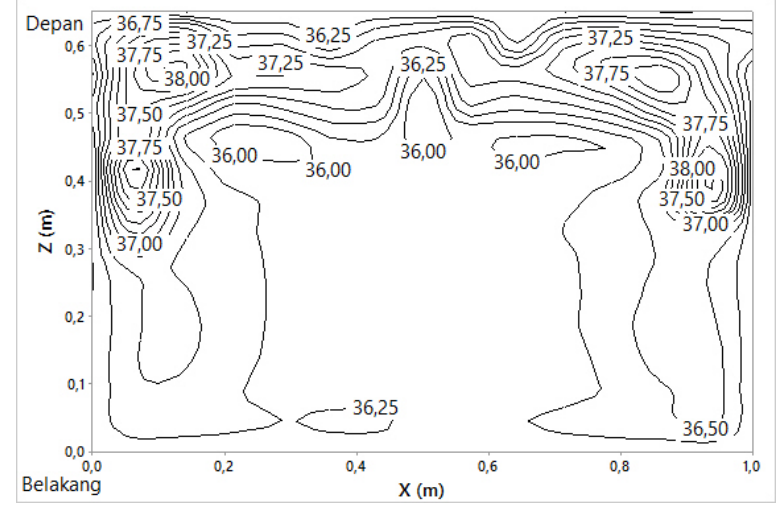

(c) Rak bawah (susunan pipa 2)

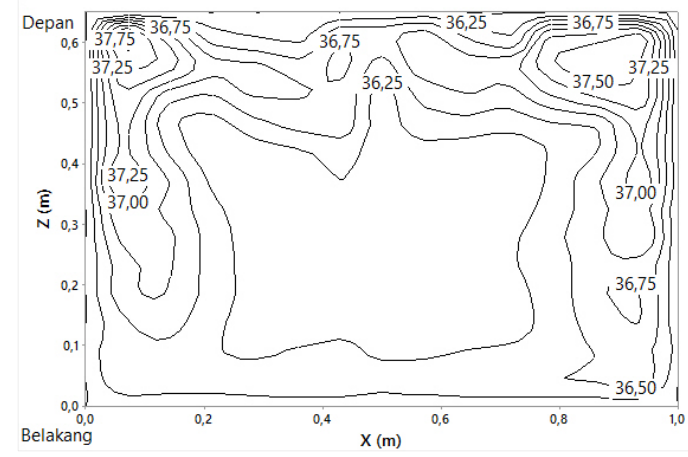

(d) Rak atas (susunan pipa 2)

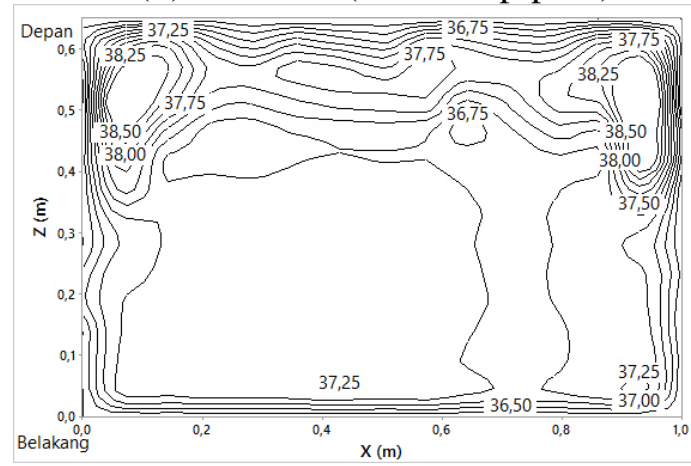

(e) Rak bawah (susunan pipa 3)

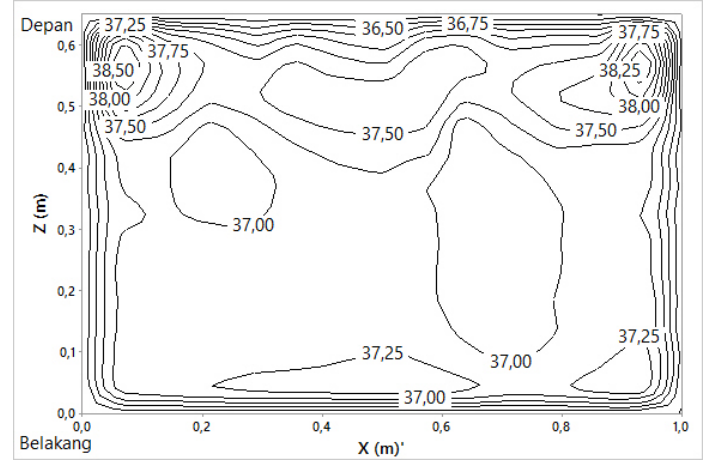

(f) Rak atas (susunan pipa 3)

Gambar 5. Distribusi temperatur udara pada tempat peletakkan rak bawah dan rak atas dengan susunan pipa yang bervariasi.

Serupa dengan inkubator dengan susunan pipa 1, pada sudut depan inkubator terdapat daerah yang memiliki temperatur lebih tinggi dibanding daerah lainnya. Hal ini terjadi baik tempat peletakkan rak bawah maupun rak atas. Fenomena ini juga disebabkan oleh adanya vortex pada sudut depan tempat peletakkan rak bawah

Pada inkubator dengan susunan pipa 3, terdapat daerah yang berada di luar temperatur pengeraman. Letak daerah yang temperaturnya lebih dari temperatur pengeraman berada di sudut depan inkubator. Temperatur pada daerah tersebut lebih dari $38,5^{\circ} \mathrm{C}$. Hal ini terjadi pada tempat peletakkan rak bawah dan rak atas inkubator telur. Hal ini disebabkan oleh adanya vortex yang terjadi pada sudut depan tempat peletakkan rak bawah inkubator telur. Untuk temperatur dominan pada inkubator dengan susunan pipa 3, pada Gambar 5 (e) dan (f) dapat dilihat bahwa pada rak bawah dan rak atas inkubator dengan susunan pipa 2 daerah terluasnya memiliki rentang temperatur 37,00 $37,25^{\circ} \mathrm{C}$.

Dari ketiga susunan pipa, fenomena yang sama terjadi, yaitu terdapat daerah yang memiliki temperatur lebih tinggi dibanding daerah lainnya yang letaknya di sudut depan inkubator telur. Penyebab dari fenomena ini adalah vortex yang terjadi pada sudut depan tempat peletakkan rak bawah. Hal ini ditunjukkan oleh kontur kecepatan arah Z yang ditunjukkan pada Gambar 6.

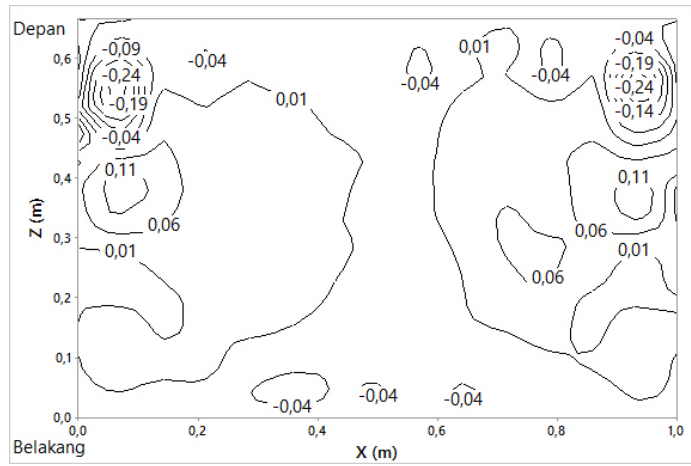

(a) Rak bawah (susunan pipa 1)

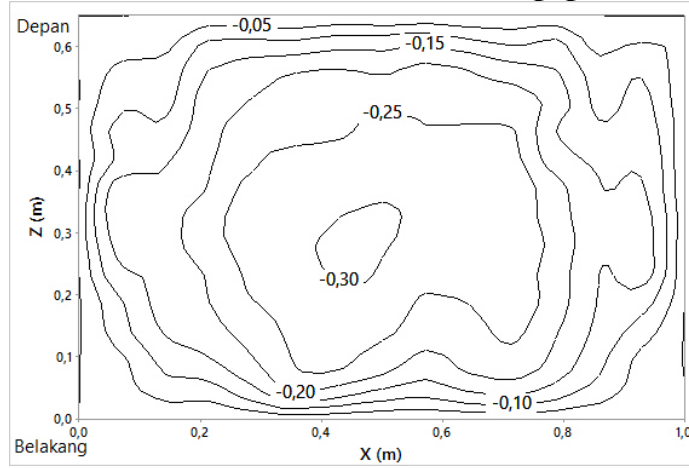

(b) Rak atas (susunan pipa 1) 


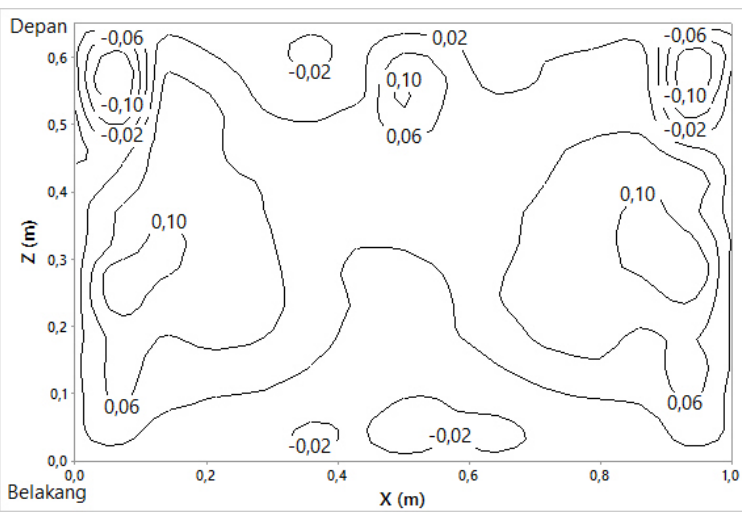

(c) Rak bawah (susunan pipa 2)

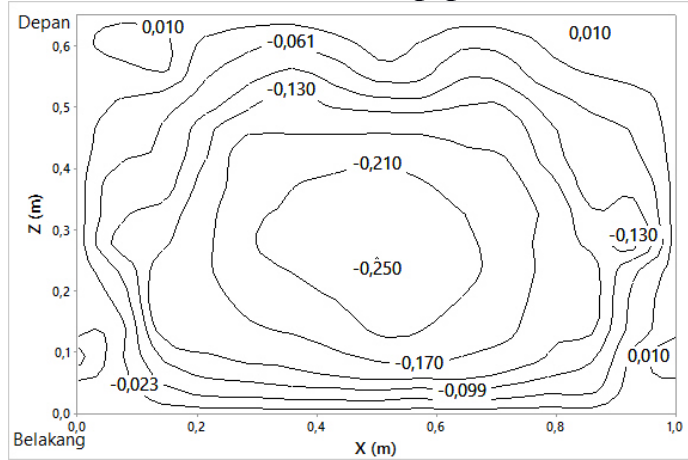

(d) Rak atas (susunan pipa 2)

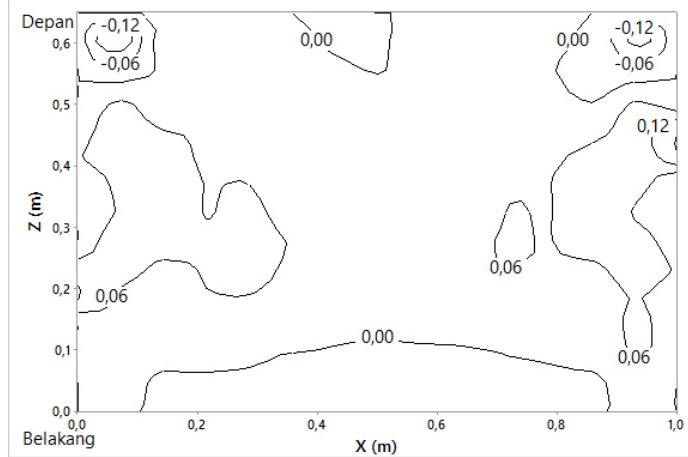

(e) Rak bawah (susunan pipa 3)

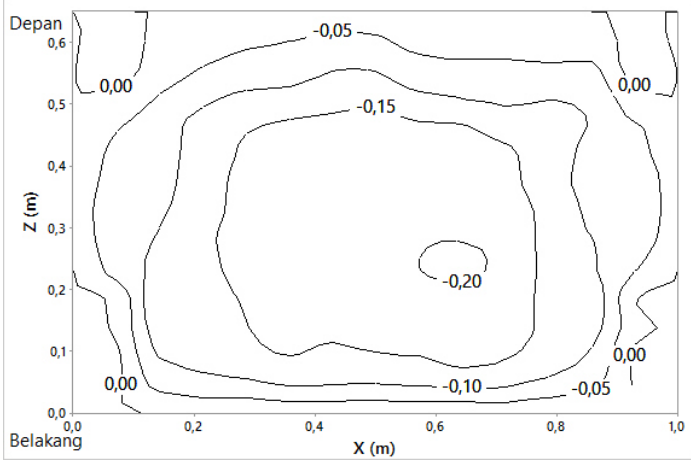

(f) Rak atas (susunan pipa 3)

Gambar 6 Kontur distribusi kecepatan arah Z pada tempat peletakkan rak bawah dan rak atas inkubator dengan susunan pipa yang bervariasi.

Gambar 6(a)- (b) merupakan gambar kontur kecepatan udara arah Z untuk inkubator telur dengan susunan pipa 1 . Kontur kecepatan udara arah $\mathrm{Z}$ menunjukkan bahwa terdapat vortex pada tempat peletakkan rak bawah sedangkan pada rak atas tidak terjadi vortex. Adanya vortex pada rak bawah ditunjukkan oleh Gambar 6(a) dimana pada sudut depan inkubator kecepatan udara arah Z bernilai $-0,24 \mathrm{~m} / \mathrm{s}$ sampai $-0,04 \mathrm{~m} / \mathrm{s}$, sedangkan disekeliling daerah tersebut terdapat kecepatan udara arah Z yang bernilai $0,01 \mathrm{~m} / \mathrm{s}$. Perbedaan tanda darh nilai kecepatan udara arah $\mathrm{Z}$ ini menunjukkan arah dari kecepatan udara pada arah Z. Hal ini lah yang menunjukkan bahwa di sudut depan inkubator pada tempat peletakkan rak bawah terdapat vortex. Pada Gambar 4.7 (b), fenomena seperti pada tempat peletakkan rak bawah tidak terjadi. Kecepatan udara hampir seluruhnya bernilai negatif (-). Hal ini berarti, kecepatan udara arah $\mathrm{Z}$ mengalir ke arah $\mathrm{Z}$ negatif. Tingginya temperatur pada tempat peletakkan rak atas tidak disebabkan karena adanya vortex yang terjadi pada tempat peletakkan rak atas, melainkan karena adanya perpindahan panas yang terjadi dari daerah vortex pada tempat peletakkan rak bawah.

Pada Gambar 6(c)- (d), ditujukkan kontur temperatur arah $\mathrm{Z}$ pada tempat peletakkan rak bawah dan rak atas inkubator dengan susunan pipa 2. Pada tempat peletakkan rak bawah yang ditunjukkan oleh Gambar 6 (c), di sudut depan inkubator juga terdapat arah kecepatan udara arah $\mathrm{Z}$ yang berbeda dibanding dengan sekelilingnya. Besar kecepatan udara arah Z di sudut depan inkubator bernilai -0,1 m/s hingga $0,06 \mathrm{~m} / \mathrm{s}$. Sedangkan, temperatur udara di sekitar daerah tersebut memiliki nilai $0,02 \mathrm{~m} / \mathrm{s}$. Hal ini lah yang juga mengindikasikan bahwa terdapat vortex pada tempat peletakkan rak bawah inkubator dengan susunan pipa 2. Pada tempat peletakkan rak atas inkubator dengan susunan pipa 2, kontur kecepatan arah $\mathrm{Z}$ tidak menunjukkan adanya vortex, seperti yang dtunjukkan pada Gambar 6 (b). Kecepatan udara arah $\mathrm{Z}$ yang terjadi pada tempat peletakkan rak atas memiliki nilai berkisar antara $-0,25 \mathrm{~m} / \mathrm{s}$ hingga $-0,061 \mathrm{~m} / \mathrm{s}$. Penyebab terjadinya daerah dengan temperatur lebih tinggi pada tempat peletakkan rak atas serupa dengan pembahasan awal, yaitu karena perpindahan panas yang terjadi dari daerah vortex di tempat peletakkan rak bawah.

Pada Gambar 6 (e) dan (f), ditujukkan kontur temperatur arah $\mathrm{Z}$ pada tempat peletakkan rak bawah dan rak atas inkubator dengan susunan pipa 3. Pada tempat peletakkan rak bawah yang ditunjukkan oleh Gambar 6(c), Besar kecepatan udara arah $\mathrm{Z}$ di sudut depan inkubator bernilai $0,12 \mathrm{~m} / \mathrm{s}$ hingga $-0,06 \mathrm{~m} / \mathrm{s}$. Sedangkan, temperatur udara di sekitar daerah tersebut memiliki nilai $0,00 \mathrm{~m} / \mathrm{s}$. Hal ini lah yang juga mengindikasikan bahwa terdapat vortex pada 
tempat peletakkan rak bawah inkubator dengan susunan pipa 3. Pada tempat peletakkan rak atas inkubator dengan susunan pipa 2, kontur kecepatan arah $\mathrm{Z}$ tidak menunjukkan adanya vortex, seperti yang dtunjukkan pada Gambar 6(b). Kecepatan udara arah Z yang terjadi pada tempat peletakkan rak atas memiliki nilai berkisar antara $-0,20 \mathrm{~m} / \mathrm{s}$ hingga $-0,05 \mathrm{~m} / \mathrm{s}$. Penyebab terjadinya daerah dengan temperatur lebih tinggi pada tempat peletakkan rak atas serupa dengan pembahasan awal, yaitu karena perpindahan panas yang terjadi dari daerah vortex di tempat peletakkan rak bawah.

\section{Pengaruh Jumlah Kipas terhadap Distribusi Temperatur Tempat Peletakkan Rak Telur}

Dalam simulasi ini, jumlah kipas sebagai penyuplai udara dibuat bervariasi. Meskipun jumlah kipas dibuat bervariasi, tetapi laju massa udara yang masuk kedalam inkubator dibuat tetap, yaitu $0,075 \mathrm{~kg} / \mathrm{s}$. Dengan laju massa total tetap dan jumlah kipas yang berubah, maka kecepatan udara yang masuk akan mengalami perubahan begitu juga laju massa udara tiap kipas. Pada Tabel 9 ditunjukkan besarnya kecepatan udara yang disuplai tiap dan laju massa udara tiap kipas jika laju massa total udara masuk dibuat tetap.

Tabel 9. Kecepatan udara dan laju massa udara tiap kipas jika laju massa total udara masuk tetap.

\begin{tabular}{|l|l|l|}
\hline $\begin{array}{l}\text { Jumlah } \\
\text { kipas }\end{array}$ & $\begin{array}{l}\text { Kecepatan } \\
\text { udara masuk } \\
\text { tiap kipas } \\
(\mathbf{m} / \mathbf{s})\end{array}$ & $\begin{array}{l}\text { Laju massa } \\
\text { udara tiap } \\
\text { kipas (kg/s) }\end{array}$ \\
\hline $\mathbf{2}$ & 3,9 & 0,0375 \\
\hline $\mathbf{4}$ & 1,95 & 0,01875 \\
\hline $\mathbf{6}$ & 1,3 & 0,0125 \\
\hline
\end{tabular}

Dalam simulasi ini, parameter jumlah kipas dibuat bervariasi dengan jumlah 2 kipas sampai 6 kipas. Parameter lain dibuat tetap, seperti yang telah dipaparkan pada Tabel 9. Temperatur udara masuk $25^{\circ} \mathrm{C}$, temperatur pipa $70^{\circ} \mathrm{C}$, susunan pipa 7 baris, dan laju massa udara total yang masuk $0,075 \mathrm{~kg} / \mathrm{s}$. Simulasi ini bertujuan untuk menganalisis pengaruh dari jumlah kipas pada distribusi temperatur di tempat peletakkan rak di inkubator telur dan juga menentukan berapa jumlah kipas yang optimal untuk menghasilkan distribusi temperatur udara yang baik untuk pengeraman telur.

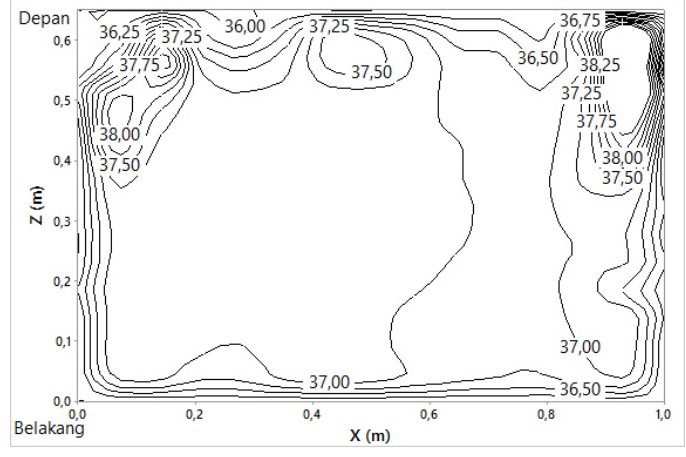

(a) Inkubator 2 kipas (b) Inkubator 3 kipas

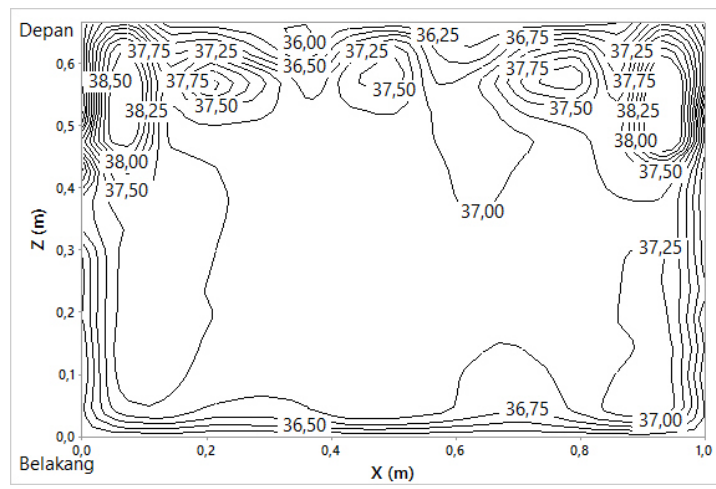

(b) Inkubator 4 kipas (d) Inkubator 5 kipas

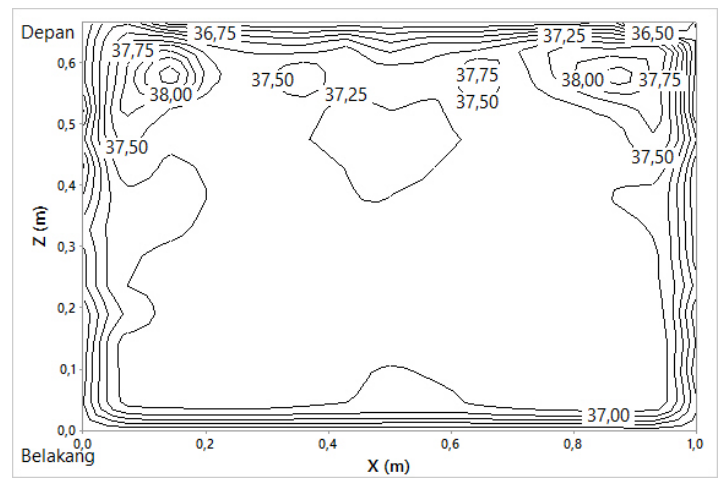

(c) Inkubator 6 kipas

Gambar 7. Distribusi temperatur udara rak bawah pada inkubator dengan jumlah kipas bervariasi.

Pada inkubator yang menggunakan 2 kipas, daerah terluas pada rak bawah memiliki temperatur dengan rentang $37,0-37,5^{\circ} \mathrm{C}$, seperti yang ditunjukkan pada Gambar 7(a) Tetapi, terdapat juga daerah yang cukup luas yang memiliki rentang temperatur $36,75-37,00^{\circ} \mathrm{C}$. Daerah ini adalah daerah yang berada diatas kipas. Selain itu, pada tempat peletakkan rak bawah dengan 2 kipas, terdapat daerah yang temperaturnya lebih dari $38,5^{\circ} \mathrm{C}$. Daerah ini terletak pada sudut depan inkubator telur. 


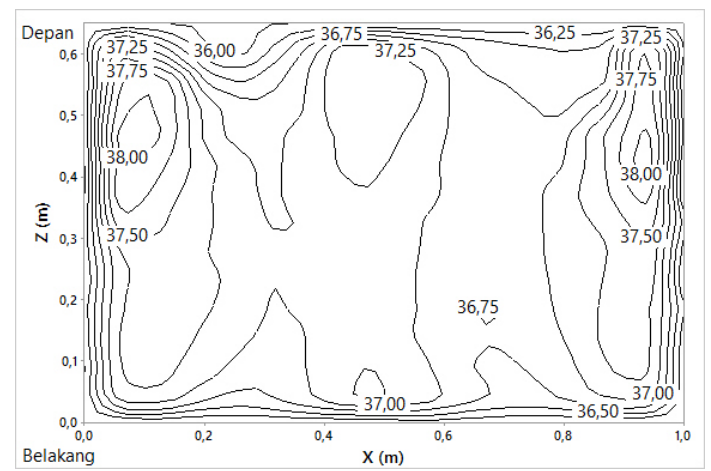

(a) Inkubator 2 kipas

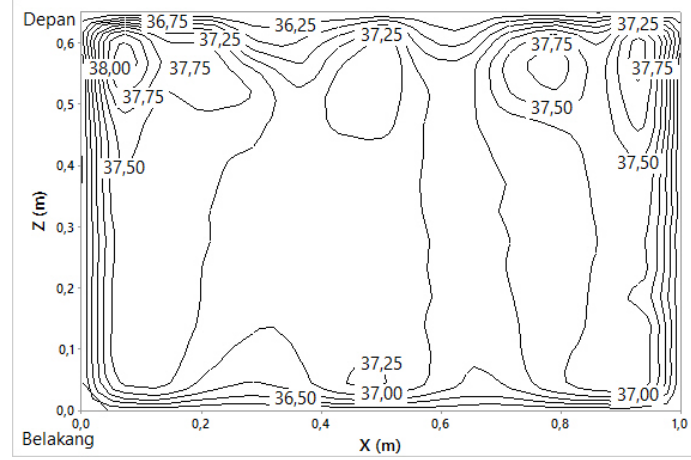

(b) Inkubator 4 kipas

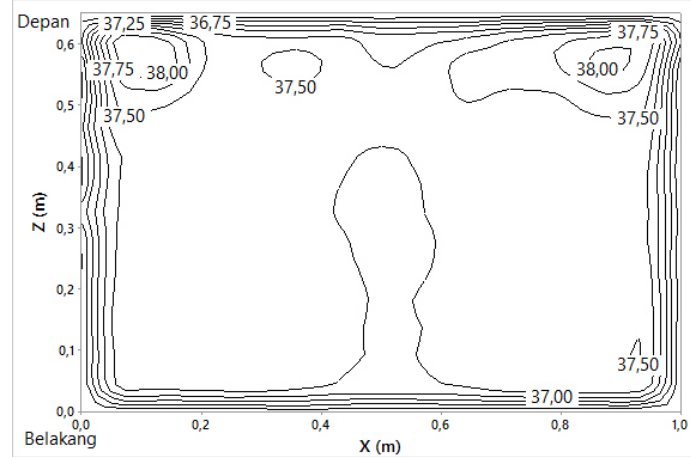

(c) Inkubator 6 kipas

Gambar 8. Distribusi temperatur udara tempat peletakkan rak atas pada inkubator dengan jumlah kipas bervariasi.

Sedangkan pada tempat peletakkan rak atas inkubator dengan 2 kipas, daerah yang memiliki rentang temperatur $37,0-37,5^{\circ} \mathrm{C}$ mengalami penyempitan. Begitu juga daerah yang temperaturnya lebih tinggi dari $38,5^{\circ} \mathrm{C}$. Sedangkan daerah yang memiliki rentang temperatur $36,75-37,00^{\circ} \mathrm{C}$ mengalami perluasan. Dapat dilihat pada Gambar 8(a), bahwa daerah dengan temperatur 36,75 $37,00^{\circ} \mathrm{C}$ mengalami perluasan

Pada inkubator yang menggunakan 4 kipas, di bagian tempat peletakkan rak bawah, masih terdapat juga daerah yang memiliki temperatur lebih dari $38,50^{\circ} \mathrm{C}$ di sudut depan inkubator. Daerah terluas memiliki temperatur udara dengan rentang $37,00-37,25^{\circ} \mathrm{C}$, seperti yang ditunjukkan oleh Gambar 8(c). Sedangkan pada tempat peletakkan rak atas, seluruh daerah telah berada pada temperatur pengeraman, seperti yang ditunjukkan pada Gambar 8(c). Pada rak atas, daerah yang memiliki temperatur 37,25 37,50 mengalami perluasan.

Pada inkubator yang menggunakan 6 kipas, seluruh temperatur udara baik di tempat peletakkan rak bawah maupun rak atas berada pada rentang temperatur pengeraman. Pada tempat peletakkan rak bawah, rentang temperatur udara adalah $36,00-38,50^{\circ} \mathrm{C}$, seperti yang ditunjukkan pada Gambar 7(c). Daerah terluas pada tempat peletakkan rak bawah berada pada rentang temperatur $37,25-37,50^{\circ} \mathrm{C}$. Temperatur tertinggi pada tempat peletakkan rak bawah adalah $38,00^{\circ} \mathrm{C}$ yang berada di sudut depan inkubator. Hal serupa juga terjadi pada tempat peletakkan rak atas, seperti yang ditunjukkan pada Gambar 8(c). Perbedaannya adalah pada tempat peletakkan rak atas memiliki daerah yang bertemperatur $37,25-37,50^{\circ} \mathrm{C}$ lebih luas.

Dari hasil studi komputasi distribusi temperatur udara inkubator telur dengan menggunakan jumlah kipas yang bervariasi, terdapat fenomena dimana temperatur udara lebih tinggi di bagian sudut depan tempat peletakkan rak bawah inkubator telur. Seperti yang telah dijelaskan sebelumnya, fenomena ini terjadi karena adanya vortex. Keberadaan vortex pada tempat peletakkan rak bawah inkubator telur dengan jumlah kipas yang berbeda dapat dilihat pada Gambar 10. Sedangkan pada tempat peletakkan rak atas, fenomena yang sama terjadi juga, dimana temperatur pada sudut depan inkubator lebih tinggi dibanding sekitarnya. Untuk tempat peletakkan rak atas, daerah dengan temperatur lebih tinggi di sudut depan inkubator terjadi karena perpindahan panas yang terjadi dari tempat peletakkan rak bawah. Karena pada tempat peletakkan rak atas tidak terdapat vortex, seperti yang ditunjukkan pada Gambar 11.

Gambar 10(a) menunjukkan kontur kecepatan udara arah $\mathrm{Z}$ pada tempat peletakkan rak bawah inkubator dengan 2 kipas. Pada bagian sudut depan inkubator, dapat terlihat bahwa kecepatan udara arah Z memiliki nilai $-0,24 \mathrm{~m} / \mathrm{s}$ hingga $-0,06 \mathrm{~m} / \mathrm{s}$. Tetapi di sekitar daerah tersebut, kecepatan udara memiliki nilai positif, yaitu $0,00 \mathrm{~m} / \mathrm{s}$. Hal ini menandakan adanya vortex pada daerah sudut depan inkubator. 


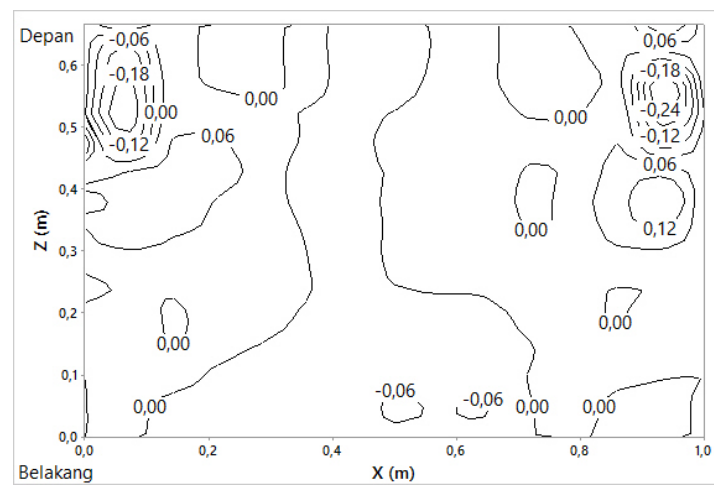

(a) Inkubator 2 kipas

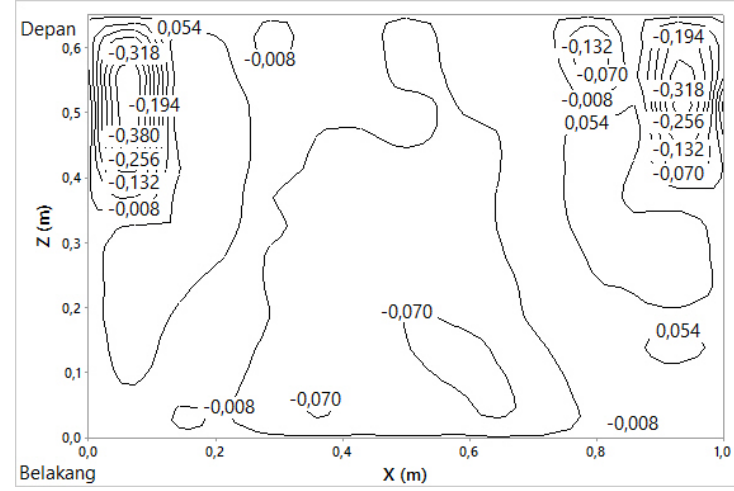

(b) Inkubator 4 kipas

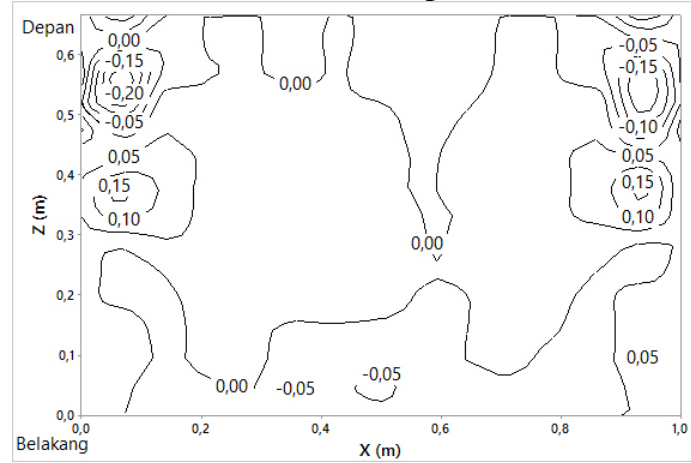

(c) Inkubator 6 kipas

Gambar 10. Kontur kecepatan arah Z pada tempat peletakkan rak bawah inkubator telur dengan jumlah kipas bervariasi

Gambar 10(b). menunjukkan kontur kecepatan udara arah $\mathrm{Z}$ pada tempat peletakkan rak bawah inkubator dengan 4 kipas. Pada bagian sudut depan inkubator, dapat terlihat bahwa kecepatan udara arah Z memiliki nilai $-0,31 \mathrm{~m} / \mathrm{s}$ hingga $-0,19 \mathrm{~m} / \mathrm{s}$. Tetapi di sekitar daerah tersebut, kecepatan udara memiliki nilai positif, yaitu $0,05 \mathrm{~m} / \mathrm{s}$. Hal ini menandakan adanya vortex pada daerah sudut depan inkubator.

Pada inkubator dengan 6 kipas, kecepatan udara arah Z tempat peletakkan rak bawahnya memiliki pola serupa dengan inkubator dengan 2 sampai 5 kipas. pada inkubator dengan 6 kipas, seperti yang ditunjukkan pada Gambar 10 (c), di sudut depan inkubator juga terdapat daerah yang arah kecepeatannya berbeda dengan sekitarnya. Pada sudut depan inkubator dengan 6 kipas, kecepatan udara arah $\mathrm{Z}$ memiliki kecepatan dengan nilai -0,15 m/s hingga $-0,05 \mathrm{~m} / \mathrm{s}$, sedangkan kecepatan udara sekitar daerah sudut memiliki kecepatan bernilai positif, yaitu 0,00 $\mathrm{m} / \mathrm{s}$ hinga $0,05 \mathrm{~m} / \mathrm{s}$. Dari pembahasan diatas, dapat disimpulkan bahwa daerah yang memiliki temperatur yang lebih tinggi di rak bawah inkubator dengan jumlah kipas berbeda disebabkan danya vortex pada daerah tersebut.

Pada tempat peletakkan rak atas inkubator telur, tidak terdapat fenomena vortex, seperti yang ditunjukkan pada Gambar 11. Daerah di sudut depan inkubator memiliki arah kecepatan yang sama dengan sekitarnya. Hal ini membuktikan tidak adanya vortex di sudut depan inkubator dengan jumlah kipas yang bervariasi.

Gambar 11(a) menunjukkan kecepatan udara arah $\mathrm{Z}$ pada tempat peletakkan rak atas inkubator dengan 2 kipas. Gambar 11(a) menunjukkan bahwa kecepatan udara arah Z memiliki nilai $-0,07 \mathrm{~m} / \mathrm{s}$ hingga $-0,31 \mathrm{~m} / \mathrm{s}$. Tidak terdapat kecepan udara dengan arah yang berbeda.

Gambar 11(b) menunjukkan kecepatan udara arah $\mathrm{Z}$ pada tempat peletakkan rak atas inkubator dengan 4 kipas. Gambar 4.11 bagian (c) menunjukkan bahwa kecepatan udara arah Z memiliki nilai $-0,05 \mathrm{~m} / \mathrm{s}$ hingga $-0,30 \mathrm{~m} / \mathrm{s}$. Tidak terdapat kecepan udara dengan arah yang berbeda. Untuk kecepatan udara arah $\mathrm{Z}$ tempat peletakkan rak atas inkubator dengan 6 kipas ditunjukkan pada Gambar 11(c). Serupa dengan Gambar 11(a)-(b) nilai kecepatan seluruhnya bernilai negatif, yag berarti arah kecepatan menuju ke arah $\mathrm{Z}$ negatif. Pada inkubator dengan 6 kipas, nilai kecepatan udara arah $\mathrm{Z}$ memiliki nilai $-0,05 \mathrm{~m} / \mathrm{s}$ hingga $-0,30 \mathrm{~m} / \mathrm{s}$.

Persebaran temperatur yang tidak merata saat menggunakan 2 kipas ini terjadi karena besarnya jarak antar kipas, sehingga kecepatan udara yang tidak merata saat melalui pipa menyebabkan terjadinya beda temperatur udara yang signifikan saat udara melewati pipa. Udara yang memiliki kecepatan lebih tinggi, akan akan memiliki temperatur yang lebih rendah setelah melewati pipa dan udara dengan kecepatan lebih rendah akan memiliki temperatur yang lebih tinggi setelah melewati pipa. Hal ini terjadi karena besarnya kecepatan udara berbanding lurus dengan besarnya laju massa yang melewati pipa. Sehingga, kapasitas panas udara pun akan lebih tinggi, dan akan menyebabkan kecilnya perbedaan temperatur. 


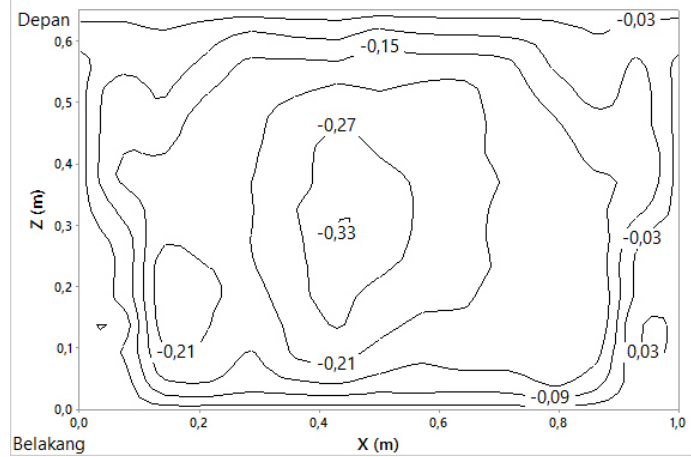

(a) Inkubator 2 kipas

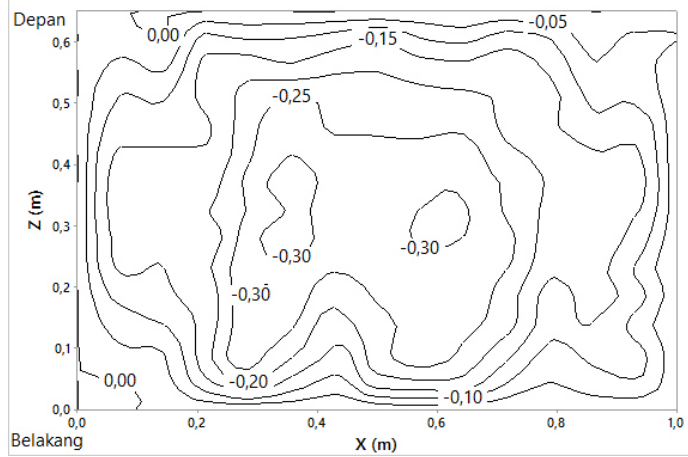

(b) Inkubator 4 kipas

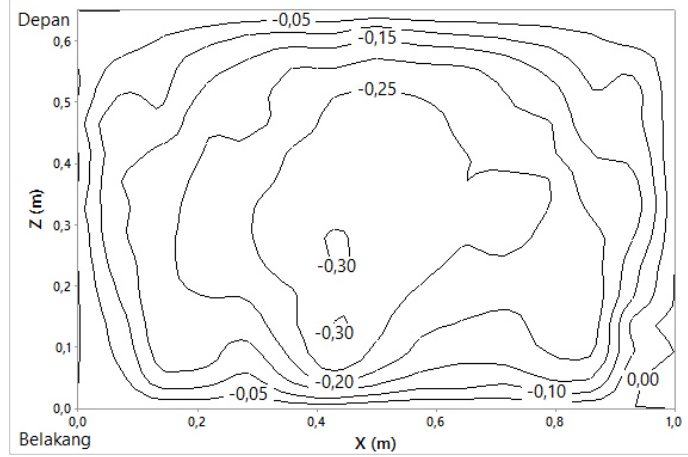

(c) Inkubator 6 kipas

Gambar 11. Kontur kecepatan arah Z pada tempat peletakkan rak atas inkubator telur dengan jumlah kipas bervariasi

\section{Pengaruh Temperatur Pipa terhadap Distribusi Temperatur Tempat Peletakkan Rak Telur}

Pengaruh temperatur pipa terhadap distribusi temperatur dalam ruangan inkubator perlu diketahui untuk menentukan temperatur pipa minimal yang dapat membuat udara pada ruangan inkubator berada pada rentang temperatur pengeraman. Dalam simulasi ini, parameter temperatur udara dibuat bervariasi, dengan nilai $70^{\circ} \mathrm{C}, 65^{\circ} \mathrm{C}, 60^{\circ} \mathrm{C}$, dan $55^{\circ} \mathrm{C}$. Parameter lainnya dibuat tetap, yaitu laju massa udara total $0,075 \mathrm{~kg} / \mathrm{s}$, temperatur udara masuk $25^{\circ} \mathrm{C}$, jumlah kipas 5 buah, dan susunan pipa 7 baris.

Pada studi komputasi ini, temperatur udara pada tempat peletakkan rak bawah sebagian besar berada pada rentang 37,00 $37,25^{\circ} \mathrm{C}$. Begitu juga pada tempat peletakkan rak atas, dengan pipa bertemperatur $70^{\circ} \mathrm{C}$ temperatur udara sebagian berada pada rentang 37,00 $37,25^{\circ} \mathrm{C}$. Distribusi temperatur udara pada tempat peletakkan rak dengan temperatur pipa $70^{\circ} \mathrm{C}$ ditunjukkan pada Gambar 12(a)-(b). Dengan temperatur pipa $65^{\circ} \mathrm{C}$, sebagian besar daerah pada tempat peletakkan rak bawah dan rak atas berada pada temperatur pengeraman, tetapi masih terdapat sedikit daerah yang berada di luar temperatur pengeraman. Pada tempat peletakkan rak bawah, daerah terluas berada pada temperatur $36,00-36,25^{\circ} \mathrm{C}$, seperti yang ditunjukkan pada Gambar 12(c). Daerah sudut depan inkubator telur memiliki temperatur udara tertinggi mencapai $37,25^{\circ} \mathrm{C}$. Pada tempat peletakkan rak atas, daerah terluas memiliki temperatur dengan rentang $36,00-36,25^{\circ} \mathrm{C}$. Temperatur tertinggi pada tempat peletakkan rak atas mencapai $36,50^{\circ} \mathrm{C}$.

Saat temperatur pipa bernilai $60^{\circ} \mathrm{C}$, hampir seluruh daerah pada inkubator telur berada diluar rentang temperatur pengeraman 36 - 38, $5^{\circ} \mathrm{C}$, seperti yang ditunjukkan pada Gambar 12(e)-(f). Pada tempat peletakkan rak bawah, daerah terluas memiliki temperatur dengan rentang $35,00-35,50^{\circ} \mathrm{C}$. Dengan temperatur tertinggi berada di daerah sudut depan inkubator dan bernilai $36,00^{\circ} \mathrm{C}$, seperti yang ditunjukkan pada Gambar 10(a). Sedangkan untuk tempat peletakkan rak atas, temperatur udara berada pada rentang $35,00-36,00^{\circ} \mathrm{C}$.

Dengan temperatur pipa $55^{\circ} \mathrm{C}$, seluruh daerah pada tempat peletakkan rak bawah dan rak atas memiliki temperatur udara yang lebih rendah dari temperatur pengeraman, seperti yang ditunjukkan pada Gambar 12(g)-(h). Pada tempat peletakkan rak bawah, temperatur udara berada pada rentang $33,75-35,00^{\circ} \mathrm{C}$, seperti yang ditunjukkan pada Gambar 12(g). Serupa dengan rak bawah, pada tempat peletakkan rak atas, temperatur udara berada pada rentang 33,75 $36,00^{\circ} \mathrm{C}$.

Hasil dari studi komputasi dengan temperatur pipa divariasikan menunjukkan bahwa temperatur pipa minimum untuk menghasilkan udara dalam ruangan inkubator berada pada rentang temperatur pengeraman adalah $65,00^{\circ} \mathrm{C}$. Karena, dengan temperatur pipa $65,00^{\circ} \mathrm{C}$, temperatur udara pada tempat peletakkan rak bawah dan rak berada pada rentang temperatur $36,00-37,25^{\circ} \mathrm{C}$ dan $35,75-36,75^{\circ} \mathrm{C}$. Untuk kasus temperatur pipa dengan temperatur $60,00^{\circ} \mathrm{C}$ dan $55,00^{\circ} \mathrm{C}$ distribusi temperatur pipa pada ruangan inkubator tidak mencapai temperatur pengeraman.

Menurunnya nilai temperatur pipa, maka nilai laju perpindahan panas dari pipa ke udara 
pun menurun. Hal ini lah yang menyebabkan temperatur pipa dibawah $65,00^{\circ} \mathrm{C}$ mengasilkan temperatur udara yang lebih rendah dari tempertur pengeraman. Pipa dengan temperatur dibawah $65,00^{\circ} \mathrm{C}$ tidak cukup untuk menaikkan temperatur udara dengan laju massa $0,075 \mathrm{~kg} / \mathrm{s}$ dari temperatur $25,00^{\circ} \mathrm{C}$ ke $36,00-37,50^{\circ} \mathrm{C}$.

Cara yang dapat digunakan untuk mencapai temperatur pengeraman dengan temperatur pipa dibawah $65^{\circ} \mathrm{C}$ menggunakan model inkubator ini adalah adalah dengan mengatur kembali laju massa udara yang melewati pipa, atau dengan kata lain mengatur debit kipas sebagai penyuplai udara atau dengan mengatur debit fluida panas bumi yang dialirkan. Dengan laju perpindahan panas yang lebih kecil akibat lebih rendahnya temperatur pipa, maka laju massa udara atau laju massa fluida panas bumi harus diperkecil juga untuk mendapatkan beda temperatur yang lebih besar.

Kontur distribusi temperatur yang ditunjukkan pada Gambar 12, terlihat juga daerah yang memilki temperatur paling tinggi berada di sudut depan inkubator, baik ditempat peletakkan rak bawah dan rak atas. Fenomena ini terjadi karena tempat peletakkan rak bawah di bagian sudut depan, terjadi vortex, seperti yang ditunjukkan pada Gambar 13(a). Pada tempat peletakkan rak atas, daerah yang memiliki temperatur lebih tinggi terjadi karena adanya perpindahan panas dari udara pada tempat peletakkan rak atas, bukan karena adanya vortex.

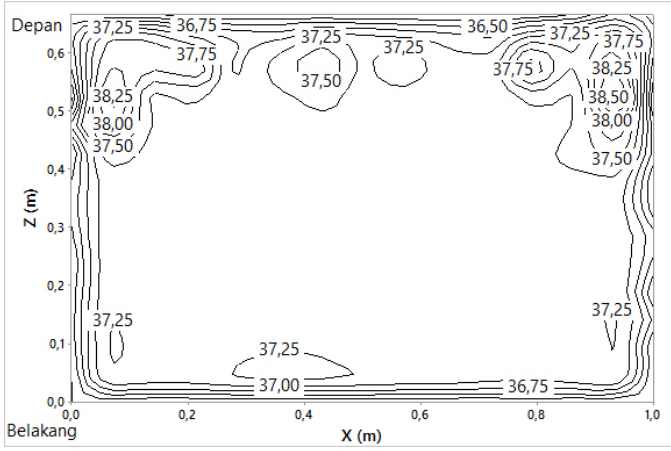

(a) Rak bawah $\left(\mathrm{T}_{\text {pipa }}=70^{\circ} \mathrm{C}\right)$

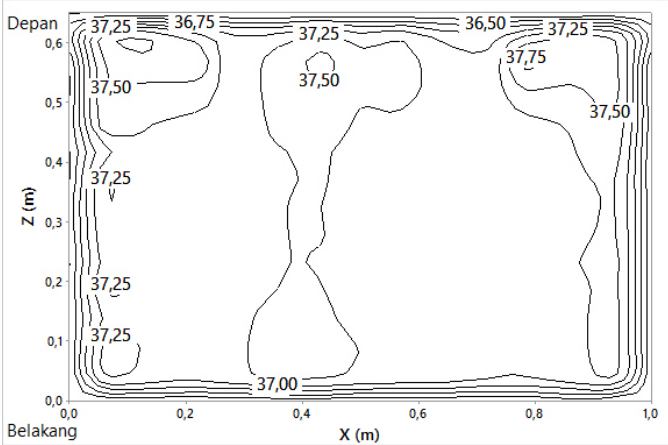

(b) Rak atas $\left(\mathrm{T}_{\text {pipa }}=70^{\circ} \mathrm{C}\right)$

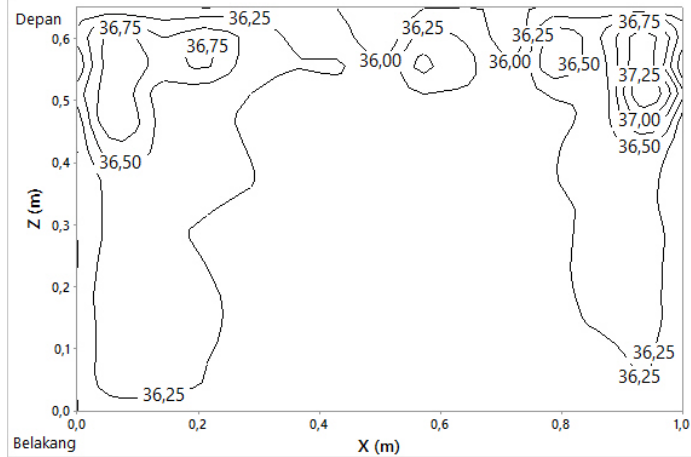

(c) Rak bawah $\left(\mathrm{T}_{\text {pipa }}=65^{\circ} \mathrm{C}\right)$

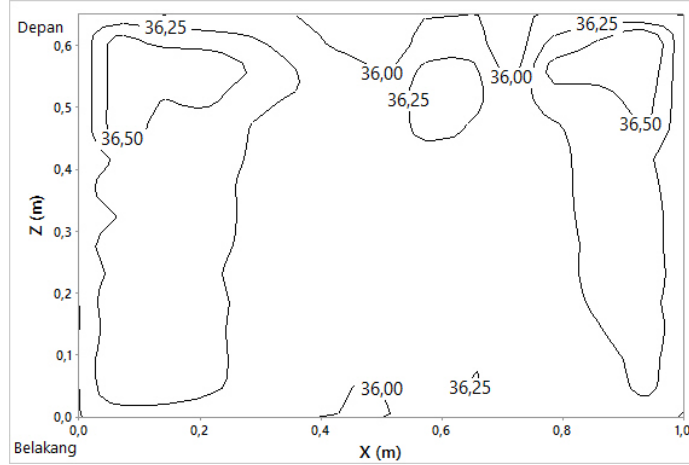

(d) Rak atas $\left(\mathrm{T}_{\text {pipa }}=65^{\circ} \mathrm{C}\right)$

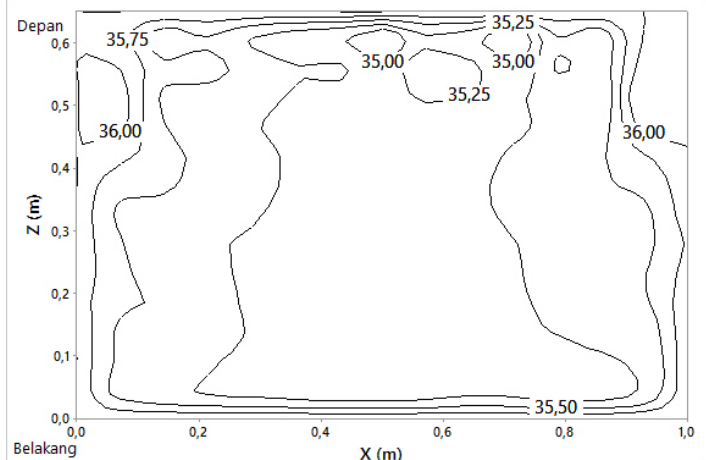

(e) Rak bawah $\left(\mathrm{T}_{\text {pipa }}=60^{\circ} \mathrm{C}\right)$

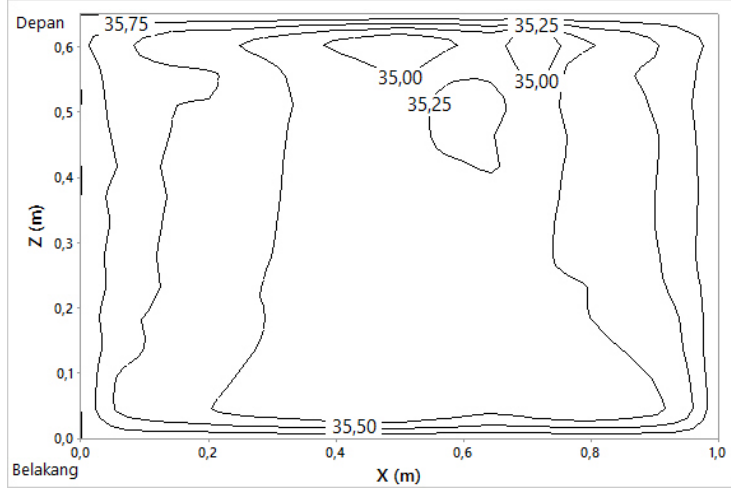

(f) Rak atas $\left(\mathrm{T}_{\text {pipa }}=60^{\circ} \mathrm{C}\right)$ 


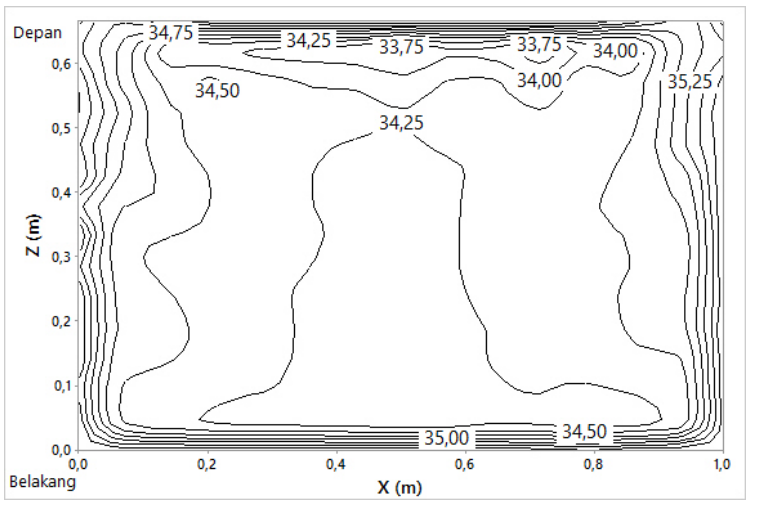

(g) Rak bawah $\left(\mathrm{T}_{\text {pipa }}=55^{\circ} \mathrm{C}\right)$

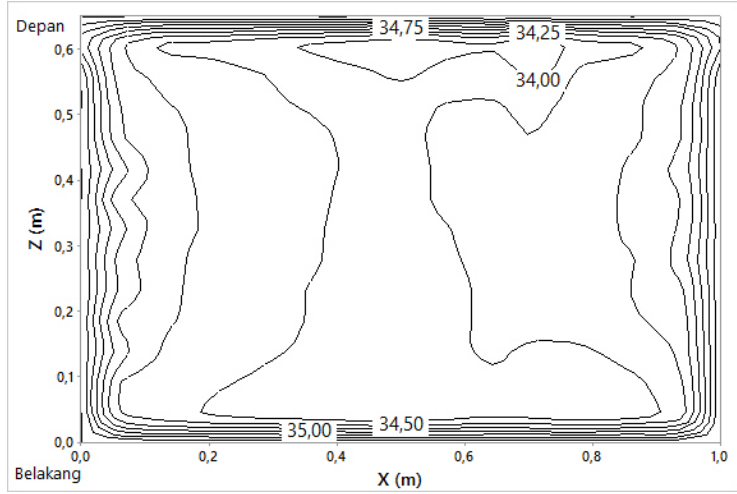

(h) Rak atas $\left(\mathrm{T}_{\text {pipa }}=55^{\circ} \mathrm{C}\right)$

Gambar 12 Distribusi temperatur udara pada inkubator dengan temperatur pipa yang

\section{Simpulan} bervariasi.

Inkubator telur dengan energi panas bumi didesain dengan komponen penukar panas, wadah air, dan kipas. Desain penukar panas yang digunakan adalah jenis cross flow heat exchanger dengan mengunakan 10 pipa tembaga dengan nominal size 1,5 tipe L. Susunan pipa tembaga berpola staggered dengan baris berjumlah 7 . Penyuplai udara yang digunakan adalah kipas dengan jumlah 4 dan massa jenis total yang disuplai adalah $0,075 \mathrm{~kg} / \mathrm{s}$. Wadah air yang digunakan berjumlah 2 buah dan memiliki luas permukaan 31x39 cm.

Distribusi temperatur yang baik pada bagian tempat peletakkan rak atas dan rak bawah dapat dicapai saat kipas yang digunakan minimal 4 buah, menggunakan susunan pipa staggered dengan jumlah baris 7 , temperatur pipa minimal $65^{\circ} \mathrm{C}$, temperatur udara yang disuplai berada pada temperatur $23-27^{\circ} \mathrm{C}$.

\section{DAFTAR PUSTAKA}

Prihatmaka, "Studi Desain Sistem Penukar Panas dengan Fluida Geotermal untuk Mesin Tetas Telur Unggas Sederhana,” Program Magister Geothermal ITB.
J. Sutcliffe, "Incubation, Natural and Artificial," 2004. http:// www.avianaquamiser.com/Incubation.pdf. [Diakses 15 Desember 2015].

Dinas Energi dan Sumber Daya Mineral Provinsi Jawa Barat, "Laporan Kegiatan Peningkatan Pemanfaatan Sumber Daya Panas Bumi di Indonesia,” Jawa Barat, 2010 